\title{
EFFECTS OF THIDIAZURON AND PACLOBUTRAZOL ON REGENERATION POTENTIAL OF TULIP FLOWER STALK EXPLANTS IN VITRO AND SUBSEQUENT SHOOT MULTIPLICATION
}

\author{
MaŁgOrZATA PodwyszyńsKa, AgNIESZKa MARASEK \\ Research Institute of Pomology and Floriculture \\ Pomologiczna 18, 96-100 Skierniewice, Poland \\ e-mail: mpodwysz@insad.pl
}

(Received: September 16, 2002. Accepted: March 31, 2003)

\begin{abstract}
The effects of TDZ and paclobutrazol on the primary regeneration on tulip flower stalk explants of six cultivars and subsequent shoot multiplication were examined. Explants, flower stalk slices, were excised from cooled and subsequently forced bulbs. The explants were incubated for two months in darkness on medium containing NAA and cytokinins, 2iP and BAP, as control, or TDZ (0.5-4 mg $\left.^{-1}\right)$ and paclobutrazol (0.05-0.4 $\left.\mathrm{mg}^{-1}\right)$. Then, the regenerating explants were subcultured on medium with TDZ and NAA applied at low concentrations. Different regeneration capabilities were found depending on cultivar and growth regulators. The percentage of explants forming leaf-like structures ranged, on the control medium, from $80 \%$ in 'Blue Parrot' and 'Prominence' to below $30 \%$ in 'Apeldoorn' and 'Mirjoran'. TDZ, applied at optimum for each cultivar concentration, greatly increased the regeneration potential up to $70-100 \%$. Paclobutrazol, added to the TDZ-containing medium, significantly enhanced the response of explants, resulting in high numbers of leaf-like structures formed per explant (13.7-22.8). The structures developed gradually into characteristic forms: the growing up cotyledonary leaf, the probable root primordium formed at its base, the growing downwards stolon and the shoot meristem developed finely on its tip. It is suggested that such primary regeneration may have a nature of somatic embryogenesis. Then, the adventitious shoots developed and formed clusters, which were divided into 2-3 smaller ones every two months. The growth regulators, used at initial stage, markedly influenced subsequent shoot multiplication. Thus, the most intensive shoot formation was noted with TDZ at concentrations of $0.5-2 \mathrm{mg} \mathrm{l}^{-1}$ and paclobutrazol of 0.05-0.1 $\mathrm{mg} \mathrm{l}^{-1}$.
\end{abstract}

KEY WORDS: tulip, regeneration in vitro, micropropagation, thidiazuron, paclobutrazol, somatic embryogenesis.

\section{INTRODUCTION}

The natural rate of a tulip vegetative propagation is insufficient for modern breeding. It takes about 25 years from the crossing to the commercial release of a new tulip cultivar. Traditional breeding has been the most important method hitherto, however it is a lengthy process. Breeding works can be intensified by the use of in vitro techniques. Therefore, several studies on tulip regeneration, multiplication and selection have been undertaken. Development of

\footnotetext{
Abbreviations:

BAP - 6-benzylaminopurine, kinetin - 6-furfurylaminopurine, 2iP - 6-( $\gamma, \gamma$-dimethylallylamino)purine, NAA - $\alpha$-naphthaleneacetic acid, TDZ - N-phenyl-N'-1,2,3-thiadiazol-5-ylurea (thidiazuron), paclobutrazol (2-RS, 3-RS)-1-(4-chlorophenyl)-4,4-dimethyl-2-(1,2,4-triazol-1-yl)-pentan-3-ol, flurprimidol - $\alpha$-(1-methylethyl-[ $\alpha-4$-(trifluromethyloxy) phenyl]-5-pyrimidinemethanol
}

shoots and bulbs from axillary buds isolated from tulip bulbs was studied by Rivière and Muller (1976). However, axillary buds revealed generally a low multiplication potential (Hulscher et al. 1992). The direct formation of adventitious bulbs on tulip scales in vitro under the influence of 2,4-D and kinetin was noted by Nishiuchi $(1979,1980)$. Induction of buds on scale explants was also observed by Rivière and Muller (1979). However, positive effects for scale explants were noted only in some genotypes. A relatively high regeneration potential was found in the nodal segments of flower stalks (isolated from bulbs stored at $17^{\circ} \mathrm{C}$ ) incubated in light (16 photoperiod) in the presence of NAA and BAP, both at the concentration of $1 \mathrm{mg} \mathrm{l}^{-1}$. Significant progress in formation of the characteristic for tulip leaf-like structures on flower stalk nodal segments was achieved by Le Nard et al. (1987) who obtained a high percentage of regenerating explants $(60-90 \%)$, due to their in- 
cubation in darkness and addition of $2 \mathrm{iP}\left(3-5 \mathrm{mg} \mathrm{l}^{-1}\right)$ to the medium containing NAA and BAP. The regeneration capacity of flower stalk explants has been influenced by several factors. Among them, the physiological status of flower stalk and explant position, with nodal segment possessing the highest regeneration potential, have been considered as the most important (Le Nard et al. 1987; Baker et al. 1990; Alderson and Taeb 1990). Thus, the highest regeneration capacity was found in immature and short floral stems isolated in November or December from bulbs stored at $17^{\circ} \mathrm{C}$ rather then in higher temperatures of $20-23^{\circ} \mathrm{C}$. On the other hand, the potential for regeneration was also noted in flower stalks isolated from bulbs subjected to the normal cold treatment used for forcing (Hulscher et al. 1992). But it was generally lower than that noted in explants derived from non-cooled bulbs. Replacement of the most commonly used cytokinins (BAP and 2iP) with zeatin $\left(1 \mathrm{mg} \mathrm{l}^{-1}\right)$ enhanced regeneration capacity (Hulscher et al. 1992; Kuijpers and Langens-Gerrits 1997). Moreover, the latter authors found that application of methyljasmonate or paclobutrazol during the initial stage improved meristem formation in regenerants. The presence of such meristem at the base of a leaf-like structure was found as a prerequisite for further bulb formation, the process conditioning efficiency of an in vitro tulip propagation (Hulscher et al. 1992; Taeb and Alderson 1990; Podwyszyńska and Ross 2003). Significant progress in primary regeneration on flower stalk explants was obtained in our preliminary study (Podwyszyńska et al. 1997; Podwyszyńska and Rojek 2000) by application of thidiazuron instead of BAP and 2iP. That resulted in nearly $100 \%$ of flower stalk slices forming more than 10 leaf-like structures during 2-3 months. If TDZ or NAA were applied separately, the development of embryolike structures was sporadic. The effect of light quality and darkness on tulip primary regeneration was also studied (Podwyszyńska and Rojek 2000). Both red and white lights strongly inhibited the initial formation of callus and leaf-like structures. These studies also showed that after primary regeneration the adventitious shoots developed at the base of leaf-like structures, called also embryo-like structures, when transferred to a medium containing a lower level of growth regulators. Furthermore, the study on factors influencing multiplication showed that most intensive adventitious shoot formation and growth was generally noted in the presence of fructose and/or glucose, under white light, whereas red light reduced shoot multiplication by $30 \%$ (Podwyszyńska and Rojek 2000; Podwyszyńska 2001). TDZ combined with 2,4-D was also used successfully in the culture of tulip embryogenic callus (Podwyszyńska et al. 2001).

In our preliminary study, the effects of TDZ $(0.5,2.5$ and $10 \mathrm{mg} \mathrm{l}^{-1}$ ) and growth retardants, paclobutrazol and flurprimidol $\left(0.1\right.$ and $\left.1 \mathrm{mg} \mathrm{l}^{-1}\right)$, used at few extreme concentrations were tested (Podwyszyńska et. al 1997). The results show that paclobutrazol combined with $2 \mathrm{iP}$ and BAP or TDZ stimulated regeneration only in the case of some cultivars, flurprimidol, however, caused generally deformation of the structures. In the present study, the effects of TDZ and paclobutrazol used at a narrower spectrum of concentrations on a primary regeneration in tulip flower stalk explants and subsequently in an adventitious shoot multiplication were examined. Morphological and histological observations were also performed.

\section{MATERIALS AND METHODS}

The experiments were performed with six tulip (Tulipa gesneriana L.) cultivars: 'Apeldoorn', 'Blenda', 'Blue Parrot', 'Lustige Witwe', 'Mirjoran' and 'Prominence'. Initial explants - flower stalk slices were isolated from bulbs cooled at $5^{\circ} \mathrm{C}$ from September for 16 weeks and then forced in darkness at $10^{\circ} \mathrm{C}$ until the obtainment of the $2-5 \mathrm{~cm}$ long flower stalks (7-10 days). Bulbs were surface-disinfected with $3 \%$ Chloramine $\mathrm{T}$ and $0.1 \% \mathrm{HgCl}_{2}$ and rinsed in sterile water. The 15-20 initial explants - stalk slices at a thickness of $2 \mathrm{~mm}$ were cut from the middle part of stalk, the 2$4 \mathrm{~mm}$ basal and upper (proximal) stalk fragments were removed. The explants were placed on the medium containing Murashige and Skoog (1962) macro- and microelements and Nishiuchi (1979) organic components, solidified with $0.7 \%$ Agar-Agar (Sigma-Aldrich, Co. Poland) and supplemented with NAA at concentration of $1 \mathrm{mg} \mathrm{l}^{-1}$ and cytokinins, $5 \mathrm{mg} \mathrm{l}^{-1} 2 \mathrm{iP}$ and $1 \mathrm{mgl}^{-1} \mathrm{BAP}$, as the control or TDZ and growth retardant, paclobutrazol, applied at different concentrations. All treatments contained five replications, each consisting of 3-6 initial explants placed in a 100 $\mathrm{ml}$ Erlenmeyer flask containing $25 \mathrm{ml}$ of a medium. Explants were incubated in darkness for 10 weeks. Then the percentage of the explants regenerating leaf-like-structures and the number of such structures per explant were noted. Subsequently, all regenerating explants were transferred on a medium supplemented with TDZ and NAA, both at $0.1 \mathrm{mg}^{-1}$ and cultured at a temperature of $23^{\circ} \mathrm{C}$ under 16 -h photoperiod provided by warm, white fluorescent light (Philips TLD 36W/95; photosynthetic photon flux density of $\left.40 \mu \mathrm{mol} \mathrm{m} \mathrm{m}^{-2} \mathrm{~s}^{-1}\right)$. In such conditions the developing adventitious shoots formed clusters, which were divided into smaller ones and subcultured onto the fresh medium every two months. The after effect of the growth regulators, used in the initial stage, on shoot multiplication was evaluated 8 months later (after four the two-monthsubcultures). The total numbers of adventitious shoots obtained from one flower stalk (one bulb) in each primary treatment were counted.

For histological analyses, the regenerating structures were fixed in CrAF for $48 \mathrm{~h}$, dehydrated through alcohol series, embedded in paraffin and sectioned to $15 \mu \mathrm{m}$ on a rotary microtome, stained with safranine - fast green, mounted in Canada balsam and examined by conventional light microscopy.

Data concerning the numbers of leaf-like structures were subjected to analysis of variance and the means compared by Duncan's test at $\mathrm{P}<0.05$. The standard errors of the difference of the mean (SE) from each analysis are presented in Table 1 and 2.

\section{RESULTS AND DISCUSSION}

Different regeneration capability was found, depending on the tulip cultivar and applied growth regulators. On the control medium containing $2 \mathrm{iP}$ and $\mathrm{BAP}$, the highest regeneration potential was found for 'Blue Parrot' and 'Prominence' (over $80 \%$ of stalk explants produced leaf-like structures), then 'Lustige Witwe' and 'Blenda' (over 60\%), 'Mirjoran' (28.6\%), the poorest one was noted for 'Apeldoorn' (14.3\%) (Table 1). The results showed that applica- 
TABLE 1. Effect of TDZ on regeneration of leaf-like structures on the flower stalk explants of tulip. Control medium contained 5 mg $\mathrm{l}^{-1}$ of $2 \mathrm{iP}$ and 1 mg $\mathrm{l}^{-1}$ of BAP, all of the media contained $1 \mathrm{mg} \mathrm{l}^{-1} \mathrm{NAA}$.

\begin{tabular}{|c|c|c|c|c|c|c|}
\hline \multirow{2}{*}{$\begin{array}{l}\text { Growth } \\
\text { regulators } \\
\left(\mathrm{mg} \mathrm{l}^{-1}\right)\end{array}$} & \multicolumn{6}{|c|}{ Cultivar } \\
\hline & Apeldoorn & Blenda & Blue Parrot & $\begin{array}{l}\text { Lustige } \\
\text { Witwe }\end{array}$ & Mirjoran & Prominence \\
\hline & \multicolumn{6}{|c|}{$\%$ regenerating explants } \\
\hline Control & 14.3 & 60.0 & 86.7 & 66.7 & 28.6 & 83.3 \\
\hline TDZ 0.5 & 93.3 & 33.3 & 73.7 & 100.0 & 75.0 & 100.0 \\
\hline TDZ 1 & 100.0 & 14.3 & 73.7 & 92.9 & 73.4 & 100.0 \\
\hline TDZ 2 & 87.5 & 93.3 & 60.0 & 100.0 & 71.4 & 100.0 \\
\hline \multirow[t]{2}{*}{ TDZ 4} & 93.8 & 66.7 & 93.3 & 93.3 & 71.4 & 100.0 \\
\hline & \multicolumn{6}{|c|}{ No. of leaf-like structures per initial explant } \\
\hline Control & $0.0 \mathrm{a}$ & $2.7 \mathrm{~b}$ & $4.3 \mathrm{a}$ & $0.5 \mathrm{a}$ & $0.4 \mathrm{a}$ & $11.1 \mathrm{a}$ \\
\hline TDZ 0.5 & $0.9 \mathrm{ab}$ & $1.3 \mathrm{ab}$ & $3.5 \mathrm{a}$ & $4.5 \mathrm{bc}$ & $2.8 \mathrm{ab}$ & $17.6 \mathrm{~b}$ \\
\hline TDZ 1 & $2.4 \mathrm{~b}$ & $0.2 \mathrm{a}$ & $3.9 \mathrm{a}$ & $5.1 \mathrm{bc}$ & $5.0 \mathrm{~b}$ & $18.2 \mathrm{~b}$ \\
\hline TDZ 2 & $2.4 \mathrm{~b}$ & $7.0 \mathrm{c}$ & $2.6 \mathrm{a}$ & $7.4 \mathrm{c}$ & $4.9 \mathrm{~b}$ & $17.9 \mathrm{~b}$ \\
\hline TDZ 4 & $3.0 \mathrm{~b}$ & $5.6 \mathrm{c}$ & $5.5 \mathrm{a}$ & $3.5 \mathrm{~b}$ & $3.0 \mathrm{ab}$ & $14.6 \mathrm{ab}$ \\
\hline SE & 0.996 & 1.074 & 1.326 & 1.400 & 1.708 & 2.501 \\
\hline
\end{tabular}

Means for each cultivar marked with the same letter do not differ significantly $(\mathrm{P}<0.05$; Duncan's multiple range test).

TABLE 2. Effect of paclobutrazol added to the media containing $1 \mathrm{mg} \mathrm{l}^{-1} \mathrm{NAA}$ and $1 \mathrm{mg} \mathrm{l}^{-1} \mathrm{TDZ}$ (control) on regeneration of leaf-like structures on the flower stalk explants of tulip.

\begin{tabular}{|c|c|c|c|c|c|c|}
\hline \multirow{2}{*}{$\begin{array}{l}\text { Paclobutrazol } \\
\left(\mathrm{mg} \mathrm{l}^{-1}\right)\end{array}$} & \multicolumn{6}{|c|}{ Cultivar } \\
\hline & Apeldoorn & Blenda & Blue Parrot & $\begin{array}{l}\text { Lustige } \\
\text { Witwe }\end{array}$ & Mirjoran & Prominence \\
\hline & \multicolumn{6}{|c|}{$\%$ regenerating explants } \\
\hline 0.0 & 100.0 & 93.3 & 100.0 & 100.0 & 73.4 & 83.3 \\
\hline 0.05 & 100.0 & 65.0 & 100.0 & 93.3 & 86.7 & 100.0 \\
\hline 0.1 & 100.0 & 80.0 & 93.3 & 93.3 & 100.0 & 100.0 \\
\hline 0.2 & 100.0 & 90.0 & 78.6 & 86.7 & 100.0 & 100.0 \\
\hline \multirow[t]{2}{*}{0.4} & 100.0 & 75.0 & 100.0 & 100.0 & 100.0 & 100.0 \\
\hline & \multicolumn{6}{|c|}{ No. of leaf-like structures per initial explant } \\
\hline 0.0 & $1.2 \mathrm{a}$ & $8.5 \mathrm{ab}$ & $7.0 \mathrm{a}$ & $2.8 \mathrm{a}$ & $5.3 \mathrm{a}$ & $16.1 \mathrm{a}$ \\
\hline 0.05 & $1.3 \mathrm{a}$ & $8.5 \mathrm{ab}$ & $14.1 \mathrm{~b}$ & $3.4 \mathrm{a}$ & $8.8 \mathrm{a}-\mathrm{c}$ & $17.4 \mathrm{a}$ \\
\hline 0.1 & $1.5 \mathrm{a}$ & $6.1 \mathrm{a}$ & $12.8 \mathrm{ab}$ & $4.5 \mathrm{a}$ & $13.1 \mathrm{c}$ & $19.1 \mathrm{a}$ \\
\hline 0.2 & $3.8 \mathrm{a}$ & $13.7 \mathrm{~b}$ & $10.3 \mathrm{ab}$ & $8.1 \mathrm{ab}$ & $12.1 \mathrm{c}$ & $22.8 \mathrm{a}$ \\
\hline 0.4 & $1.8 \mathrm{a}$ & $7.3 \mathrm{a}$ & $11.6 \mathrm{ab}$ & $15.5 \mathrm{~b}$ & $6.3 \mathrm{ab}$ & $19.9 \mathrm{a}$ \\
\hline SE & 1.145 & 2.410 & 2.558 & 2.400 & 2.745 & 2.985 \\
\hline
\end{tabular}

Means for each cultivar marked with the same letter do not differ significantly ( $\mathrm{P}<0.05$; Duncan's multiple range test).

tion of TDZ greatly increased the regeneration potential of the flower-stalk slices (Table 1). The percentage of explants forming leaf-like structures increased, as early as at $0.5 \mathrm{mg} \mathrm{l}^{-1}$ of TDZ concentration, up to $75 \%$ in 'Mirjoran', 93.3\% in 'Apeldoorn' and 100\% in 'Lustige Witwe' and 'Prominence'. When TDZ was applied at concentration of $0.5-2 \mathrm{mg} \mathrm{l}^{-1}$, also a considerably higher number of leaf-like structures per explant were noted, as compared with the control. Such effects were observed in all the studied cultivars except for 'Blue Parrot'. In this cultivar TDZ did not increase significantly the number of leaf-like structures per initial explant as compared with the control treatment. It is worthy of notice, that the regeneration of leaf-like structures, in all cultivars, was observed not only on the nodal segments, on which they were generally more numerous, but also on the inter-nodal fragments (data not presented). Such results correspond well with numerous data showing that TDZ, the diphenylurea derivative, induces cytokinin-like effects much more stronger than amino purine cytokinins (Huetteman and Preece 1993). The concentrations, at which TDZ is most effective are 10 to 1000 times lower than those of other plant growth regulators. Such high cytokinin activity has been attributed to the accumulation and/or synthesis of purine cytokinins (Thomas, Katterman, 1986; Hutchinson and Saxena 1996). This powerful agent has been often used for the in vitro establishment and multiplication of difficult to propagate species, significantly enhancing the formation of callus, adventitious shoots and/or embryos (Huetteman and Preece 1993; Hutchinson and Saxena 1996).

Our results showed that paclobutrazol strongly enhanced the morphogenic effect of TDZ (Table 2, Fig. 1). Depending on the paclobutrazol concentrations and cultivars, the highest numbers of leaf-like structures ranged from 13.7 in 


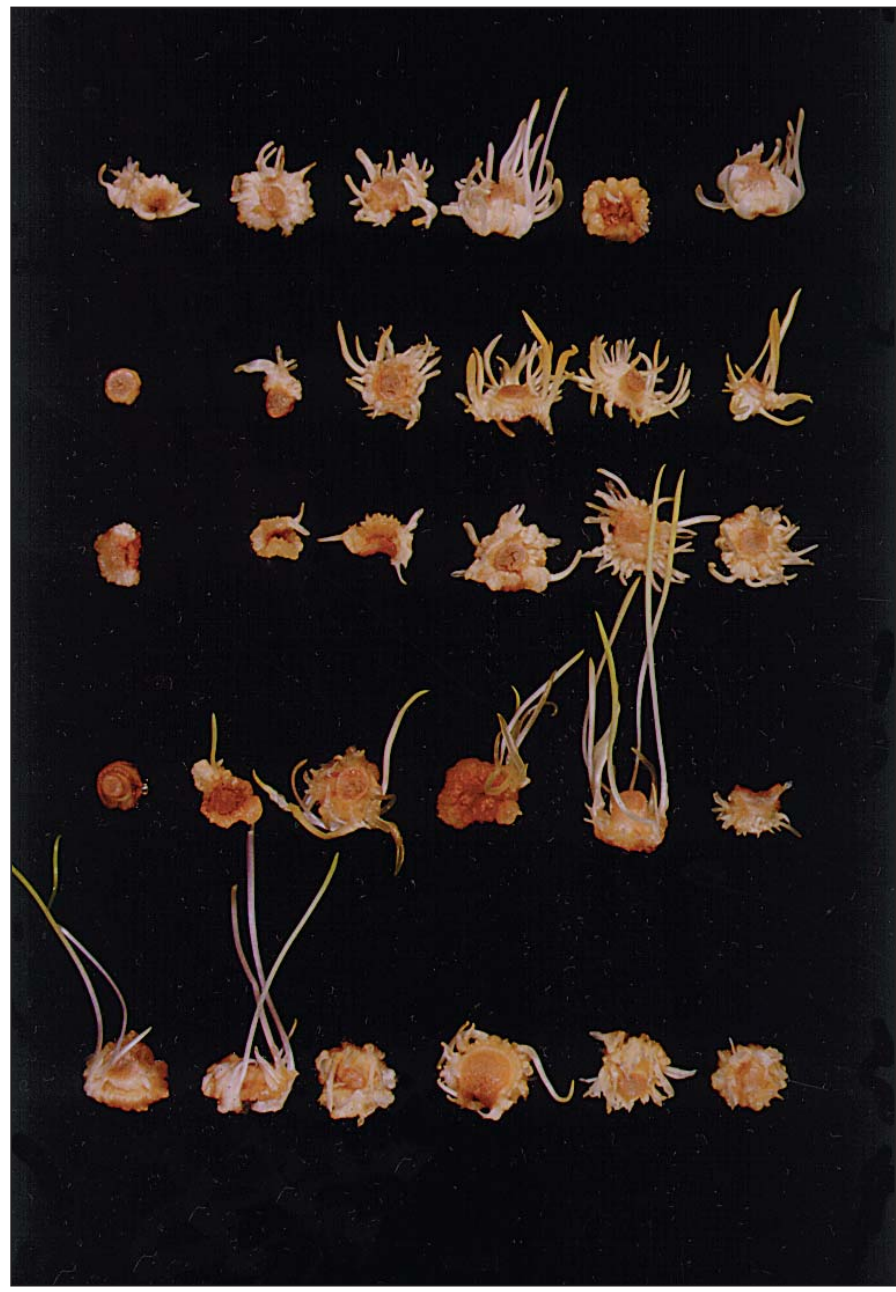

'Blenda' to 22.8 in 'Prominence', with an exception of 'Apeldoorn'. In this cultivar, 3.8 leaf-like structures were noted in the best case. The most regular structures were found at lower paclobutrazol concentrations $\left(0.05-0.1 \mathrm{mg} \mathrm{l}^{-}\right.$ $\left.{ }^{1}\right)$. Such structures were also shorter, 2-20 mm in length, whereas in the absence of growth retardant they were longer $(20-80 \mathrm{~mm})$. Paclobutrazol (a triazole derivate) reduces gibberellins' level by inhibiting kaurene oxidation in gibberellin biosynthesis (Rademacher 1991). Werbrouck and Debergh (1997) showed that paclobutrazol boosted the shoot inducing effect of cytokinin, BAP, in Spathiphyllum sp. multiplied in vitro. Paclobutrazol, like other growth retardants, ancymidol or flurprimidol, combined with cytokinins induced strong shoot proliferation (Ziv 1990; Podwyszyńska et al. 1998). Such effect of intensification of cytokinin activity can result from the fact that growth retardants increase the contents of endogenous cytokinins ( $\mathrm{Ra}-$ demacher 2000).

It is worth noting, that at higher concentrations of TDZ (2-4 $\left.\mathrm{mg} \mathrm{l}^{-1}\right)$ and paclobutrazol $\left(0.2-0.4 \mathrm{mg} \mathrm{l}^{-1}\right)$, fasciated leaf-like structures occurred (Fig. 2e). That is a relatively common phenomenon associated with a too high concentration of TDZ or its long-term use (Huetteman and Preece 1993). But shoot fasciation is usually considered as a transient trait.

In our study, after primary regeneration in darkness, the explants with developing leaf-like structures were placed in light on the fresh medium containing a lower level of TDZ and NAA. The regenerating structures developed gradually
Fig. 1. Regeneration of leaf-like structures on flower stalk explants of the five tulip cultivars (from the top: 'Blue Parrot', 'Mirjoran', 'Lustige Witwe', 'Blenda' and 'Prominence') after 10 weeks on the induction medium containing (from the left): $\left(\mathrm{mg} \mathrm{l}^{-1}\right) 52 \mathrm{iP}+1 \mathrm{BAP}+$ NAA (control), $1 \mathrm{TDZ}+1 \mathrm{NAA}+$ paclobutrazol: $0,0.05,0.1,0.2,0.4$. into characteristic forms (Fig. 2, 3). That can be regarded as a four-step process: 1) development of the growing up cotyledonary leaf; 2) then, formation of a probable root primordium at the base of cotyledonary leaf, as an axis, opposite to the initial explant (these two steps proceeded during the first two months in darkness); 3) and finally, the development of the very short or longer stolon growing downwards to the medium; 4) followed by the shoot meristem development on its tip (stolons and shoot buds developed in $3^{\text {rd }}$ and $4^{\text {th }}$ month of initial culture). Histological analysis showed that leaf-like structures dedifferentiated from the epidermal layers of stalk explants and did not show a clear vascular connection between the regenerants and maternal tissue. The further development of a primary root was never observed in any combination. The apical meristem developed, depending on the combination of growth regulators, in the empty cavity at the base of leaf-like structure (Fig. 3c) or inside of the stolon (in the presence of BAP and 2iP or TDZ at low concentration) or outside of it (usually in the presence of paclobutrazol) (Fig. 3d). Sometimes, especially at higher levels of TDZ or paclobutrazol, more stolons developed simultaneously at the base of one leaf-like structure (Fig. 2e) and/or more buds formed on the stolon apex (Fig. 2d). It is worth pointing that the formation of regular structures, consisting of cotyledonary leaf and stolon, was similar to the development of tulip seedling, except of the radicle development. It can indicate that structures observed in our study could be in fact the somatic embryos, which, however, develop under culture conditions unlike 

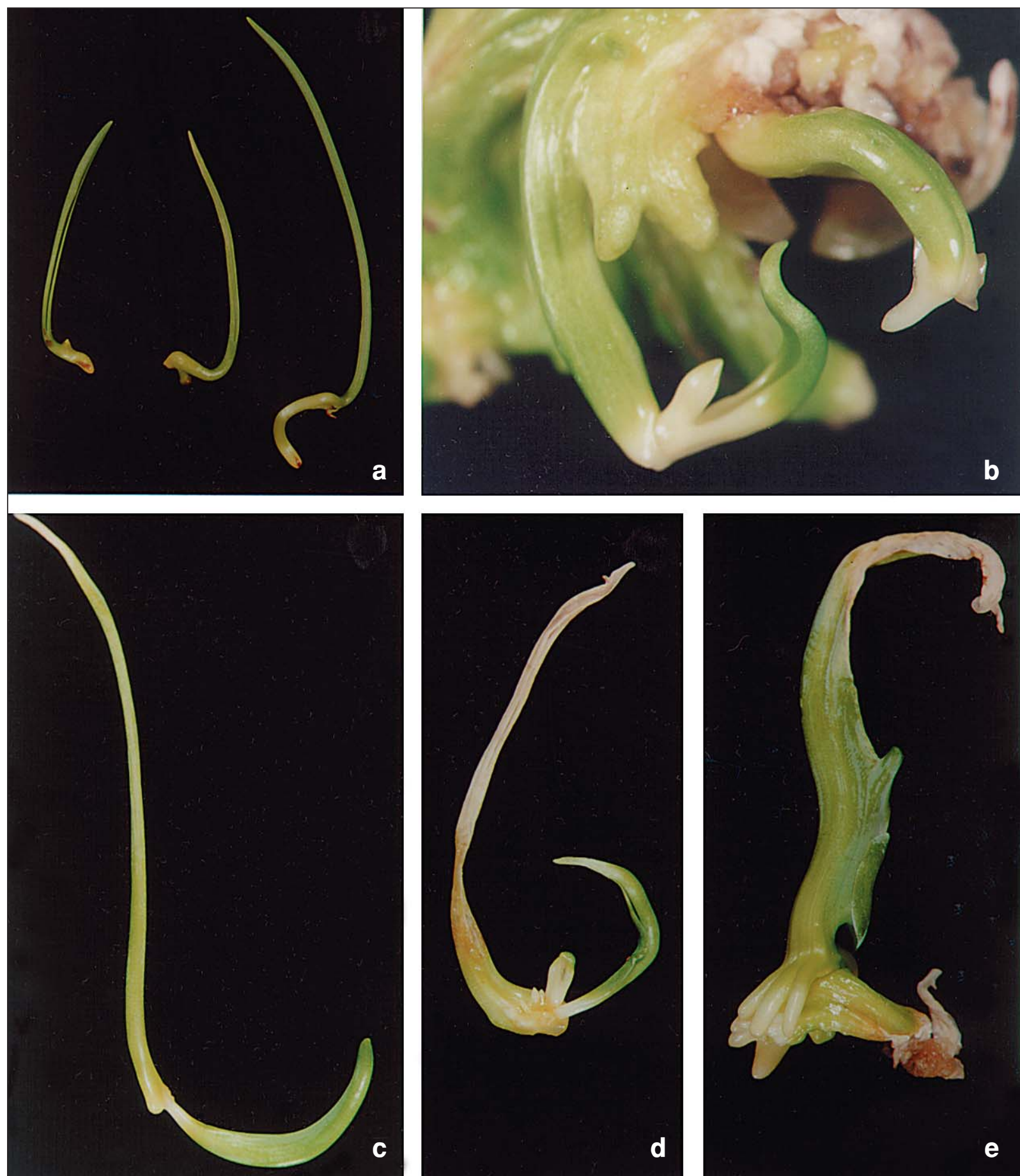

Fig. 2. Structures, similar to somatic embryos (poorly connected with maternal tissue) developing characteristic forms: growing upwards colyledonary leaf with clear basal parts often forming stolon, on its extremity developing shoots, next to the shoot bud the place of presumable undeveloped radical: a, b) 'Prominence' and c, d) 'Blue Parrot' after transfer from induction medium containing TDZ and NAA, both at $1 \mathrm{mg}^{-1}$ and subsequent 8-week exposure to TDZ and NAA at low concentration $\left(0.1 \mathrm{mg} \mathrm{l}^{-1}\right)$; e) deformed structure of 'Apeldoorn' with fasciated cotyledonary leaves and stolons developed on induction medium under influence of supra-optimal level of TDZ, $4 \mathrm{mg} \mathrm{l}^{-1}$.

the seedlings. Niimi $(1978,1980)$ reported that in tulip seeds naturally dispersed from the capsule, the embryo is immature because the vegetative apex is not fully developed. The low temperature treatment is required both to break dormancy of embryo and for further embryo development (apical bud formation). The author found, in the study on the tulip seed germination in vitro, that radicle emerged 40 days after chilling at $4^{\circ} \mathrm{C}$ and a vegetative apex began to form 70 days after low temperature treatment. Moreover, the embryo of a not chilled seed had the typical construc- tion: one of the cotyledonary procambial strands was directed to hypocotyle and the other was merged with vegetative apex. A similar arrangement of vascular tissue was observed in our study (Fig. 3b, c). Another observations of the in vitro germination of young tulip zygotic embryo, based on thermoperiodicity, showed that such embryos developed in vitro similarly to those growing in nature (Custers et al. 1992). Thus, during germination at low temperature $\left(5^{\circ} \mathrm{C}\right)$ given for 12 weeks, the embryo developed first the cotyledon which grew upward and then bent down to the 

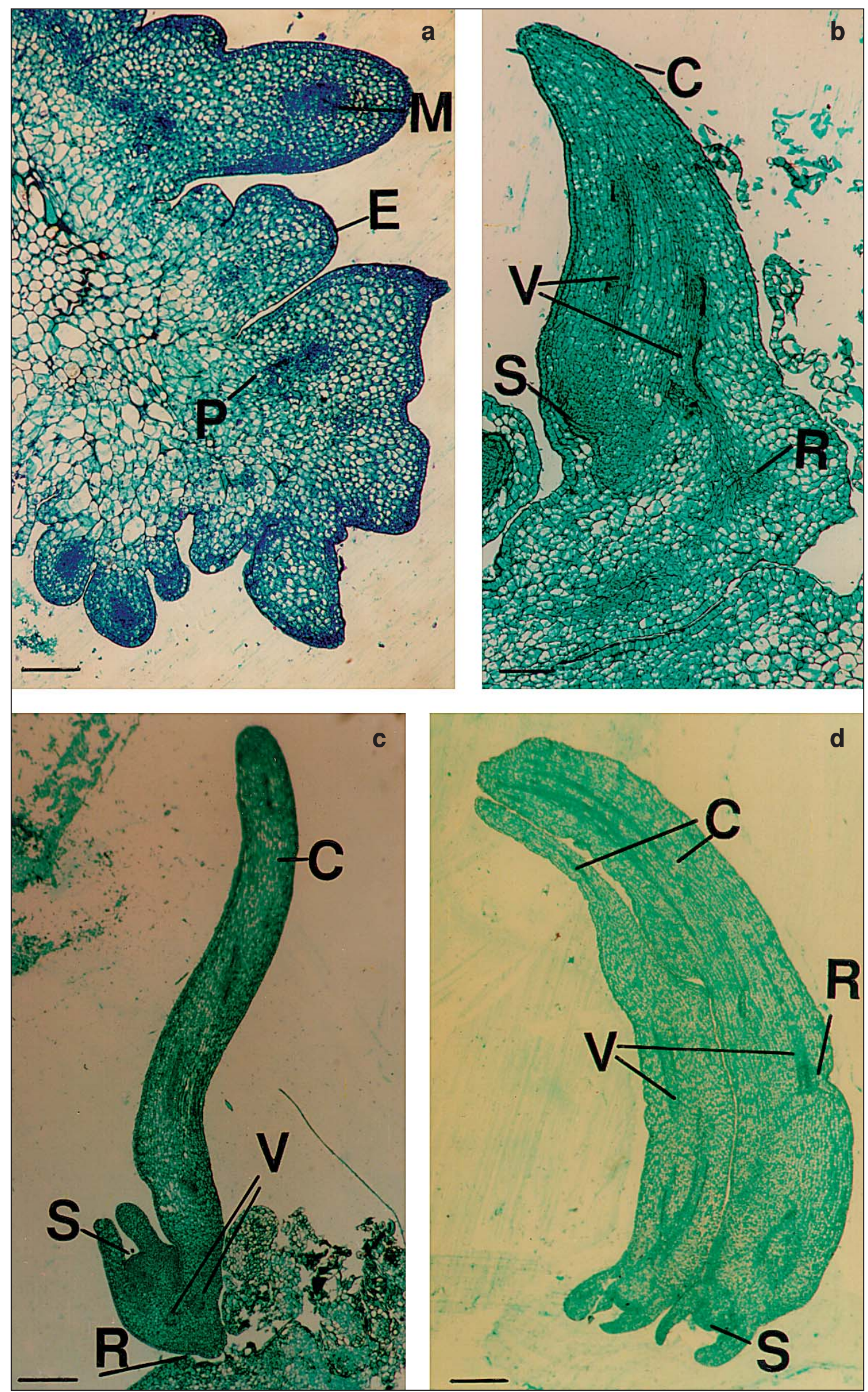

Fig 3. Histological analysis of the structures regenerated directly on the flower stalk explants: a) 'Prominence', structures at early stage of development after 8 weeks on medium containing $\left(\mathrm{mg} \mathrm{l}^{-1}\right) 52 \mathrm{iP}+1 \mathrm{BAP}+1 \mathrm{NAA}$, epidermal cells $(\mathrm{E})$, procambium $(\mathrm{P})$, meristematic cells with well visible nuclei $(\mathrm{M}), \mathrm{bar}=50 \mu \mathrm{m} ; \mathrm{b}, \mathrm{c}, \mathrm{d})$ structures without vascular connection with maternal tissue revealing characteristic forms - cotyledonary leaf (C), shoot meristem $(\mathrm{S})$ and root apex $(\mathrm{R})$ with visible vascular tissue $(\mathrm{V})$ showing a typical arrangement - one strand is directed to the hypocotyle and the second one the shoot meristem; b) 'Prominence', after 8 weeks on medium with $1 \mathrm{TDZ}+1 \mathrm{NAA}+1$ paclobutrazol, bar $=50 \mu \mathrm{m}$; c) 'Prominence', after 12 weeks on medium with $1 \mathrm{TDZ}$ and $1 \mathrm{NAA}, \mathrm{bar}=167 \mu \mathrm{m}$; d) 'Blenda', after 12 weeks on medium with $52 \mathrm{iP}+1 \mathrm{BAP}+1 \mathrm{NAA}+0.1$ paclobutrazol, bar $=167 \mu \mathrm{m}$. 

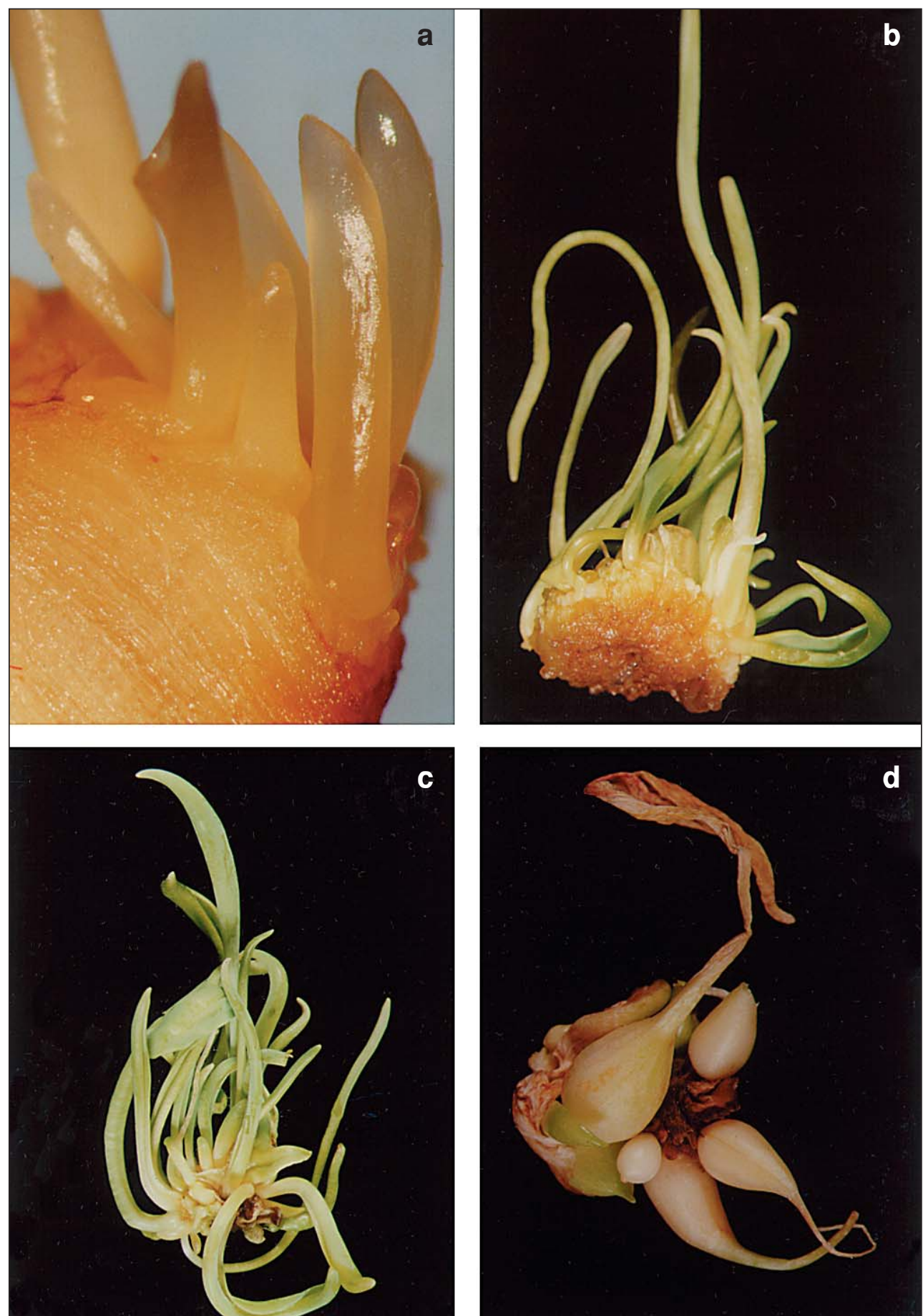

Fig. 4. Micropropagation stages of tulip: a) direct regeneration of leaf-like structures similar to somatic embryos, on flower stalk explants 10 weeks after exposure to induction medium; b) subsequent development of leaf-like structures 8 weeks after transfer onto multiplication medium; c) stabilized shoot cultures during multiplication stage; d) bulb formation in vitro on sucrose reach medium at $23^{\circ} \mathrm{C}$ in light, 8 weeks after bulb induction treatment (chilling at $4^{\circ} \mathrm{C}$ for 12 weeks).

medium. Subsequently, two organs occurred, the root and the stolon growing downward into the medium, followed by the bulblet development at its tip after transfer to a sucrose reach medium and temperature rise to $12-15^{\circ} \mathrm{C}$. The authors noted that, when the chilling period was too short, several abnormalities in embryo development occurred: seedling breakdown and a cease of root development, formation of a swollen, irregular stolon and precocious plant emergence. In our study, the further development of primary root was never observed and the shoot bud formed at the tip of the stolon in place of a bulblet (bulblet is a form of shoot transformed in the storage organ) was observed. Regarding the reports showing abnormalities in embryo development under an inadequate temperature treatment $(\mathrm{Cu}-$ sters et al. 1992, 1995), it is suggested that primary regeneration of leaf-like structures on flower stalk explants has a nature of somatic embryogenesis. That is a prolonged (sustained) process starting from cotyledon formation as the leaf-like structure, called also neoformation (Le Nard et al. 1987) or shoot without meristem (Hulscher et al 1992), followed by stolon and subsequent vegetative bud development. A similar late development, at the $12^{\text {th }}$ week of ini- 
tial regeneration, of a shoot meristem was also shown by Rice et al. (1983). Such apex (shoot/bulb primordium) formation was improved by prolonging the time of initial culture at $20^{\circ} \mathrm{C}$ from 8 to $12-16$ weeks (Rice et al. 1983; Taeb and Alderson 1990), enhancement of cytokinin level (Le Nard et al. 1987) or application of more active cytokinin, zeatin (Hulscher et al. 1992). All these authors did not call such structures somatic embryos because they did not observe the growth of radicle. We suggest that the lack of radicle can result from the culture conditions, high temperature $\left(20-23^{\circ} \mathrm{C}\right)$ maintained during the regeneration and the presence of cytokinins that are known to retard the development of roots and stimulate the formation of shoots. The inhibitory effect of TDZ on adventitious root formation was noted by several authors, e.g. in Rhododendron (Preece and Imel 1991), Vitis rotundifolia (Gray and Benton 1991).

In our study, after the two-month-culture in light, the drying cotyledonary leaves were cut off and their bases with stolons and the developing on their tips adventitious shoots were placed upside down on a fresh medium. That allowed the proper development of the shoots (Fig. 4). From that moment, the stage of multiplication began (Fig. 4c). The adventitious shoots formed clusters which were divided into 2-3 smaller ones every two months. The after-effects of growth regulators, used during the initial stage,

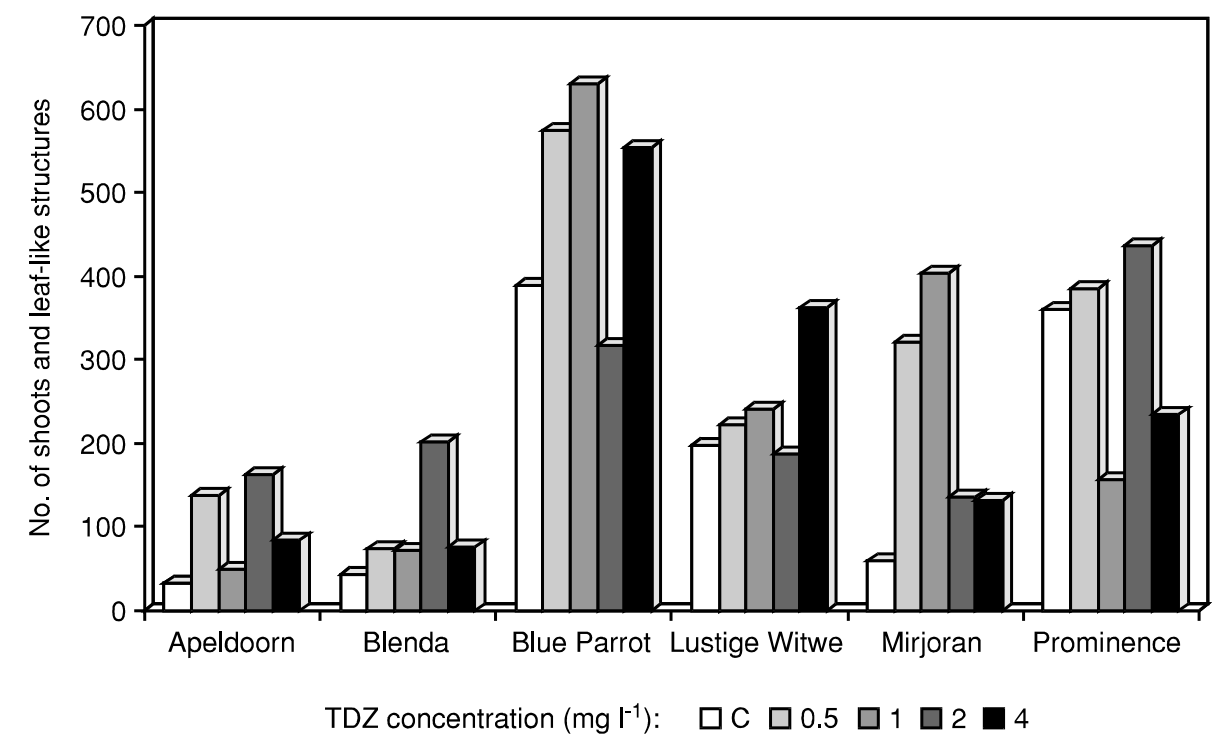

Fig. 5. The after effect of TDZ, compared to the control treatment, applied at initial stage on subsequent shoot multiplication of six tulip cultivars presented as the total shoot numbers obtained from one flower stalk (one bulb) 8 months after multiplication on medium containing TDZ and NAA at concentration of $0.1 \mathrm{mg} \mathrm{l}^{-1}$.

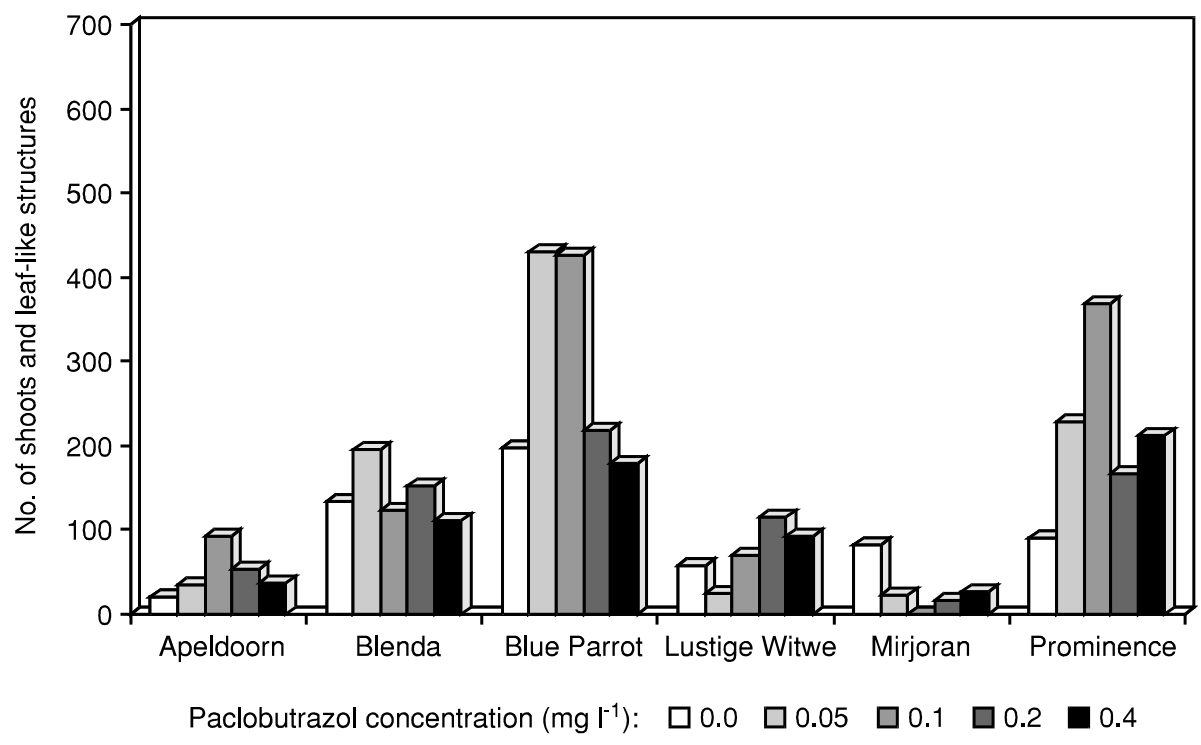

Fig. 6. The after effect of paclobutrazol, combined with TDZ and NAA both at $1 \mathrm{mg} \mathrm{l}^{-1}$, applied at initial stage on subsequent shoot multiplication of six tulip cultivars presented as the total shoot numbers obtained from one flower stalk (one bulb) 8 months after multiplication on medium containing TDZ and NAA at concentration of $0.1 \mathrm{mg} \mathrm{l}^{-1}$. 
on the further shoot growth and multiplication were noted. When the regenerating explants were subcultured on a medium containing BAP and $2 \mathrm{iP}$, the adventitious shoots ceased to develop on the stolons that formed irregular, drying structures and sometimes bulblet-like forms (data not presented). The cyclic shoot multiplication was possible only in the presence of TDZ. Data presented in figures 5 and 6 show the total number of shoots and buds obtained from the explants derived from one tulip stalk after 10 months. Thus, the application of TDZ in the induction medium at a level optimal for each cultivar permitted to obtain markedly more adventitious shoots and buds then in the case of the control induction medium. The optimal level of TDZ in the induction medium seems to be $0.5-1 \mathrm{mg} \mathrm{l}^{-1}$ for 'Mirjoran', 'Lustige Witwe' and 'Blue Parrot', $0.5 \mathrm{mg} \mathrm{l}^{-1}$ for 'Apeldoorn' and $2 \mathrm{mg} \mathrm{l}^{-1}$ for 'Prominence' and 'Blenda'. Thus, the numbers of obtained shoots were twice or even 4-5 times higher as compared with the control. Among the studied cultivars, 'Apeldoorn' had the lowest multiplication potential. In the best case, 163 shoots were noted after 10 months of the in vitro culture. In contrast, the highest multiplication intensity was noted for 'Blue Parrot' which produced 631 shoots.

The addition of paclobutrazol $\left(0.05-0.1 \mathrm{mg} \mathrm{l}^{-1}\right)$ to the induction medium containing $1 \mathrm{mg} \mathrm{l}^{-1}$ of TDZ strongly stimulated the subsequent shoot multiplication (Fig. 6). Depending on cultivar, the two- or even four times higher numbers of shoots were noted when compared with the control treatment (only TDZ). The differences between data concerning treatments with TDZ applied at $1 \mathrm{mg} \mathrm{l}^{-1}$ presented in figures 5 and 6 result probably from the different time of culture initiation. In the first case, the stalk explants were isolated in January and the second one in February.

Several attempts were undertaken to explain the poor regeneration capacity of tulip initial explants, especially those excised from scales. Van Rossum et al. (1997, 1998a, b) suggested that the damage of epidermal cell membrane, resulting from cutting the explants, might negatively affect the regeneration potential of the tissue. Such tissue damage and its low vitality were suggested due to a tulipaline release or activation of oxygen stress-related enzymes. But results of their studies did not confirm the assumption that tulipalines or oxidative stress had a direct negative effect on regeneration of tulip explants in vitro.

Thus, in the light of all these presented data it can be suggested that high regenerative potential can result from a high level of endogenously produced cytokinins under the influence of TDZ, applied at the initial stage (at higher concentrations), and during the whole multiplication process (at lower concentrations). That can be confirmed by the fact that 'Blue Parrot' revealing the highest multiplication rate (Fig. 1), responded negatively to TDZ or paclobutrazol treatment given at the initial stage, probably, due to the supra-optimal endogenous cytokinin level induced by those compounds in this cultivar. It was found that the levels of endogenous cytokinins in the shoots of 'Blue Parrot cultured in vitro were significantly higher as compared with those noted in 'Prominence' (Podwyszyńska and Ross 2003).

In conclusion, the first cyclic shoot multiplication obtained in our study, due to the application of TDZ, have a nature of adventitious shoot formation, first on a stolon tip and than on the meristematic tissue originating from the primary stolon. The remaining of such meristematic tissue as the basis, on which the clusters of shoots and buds develop, has been the prerequisite for further success in tulip propagation in vitro. Removing of such basal tissue and separation of individual shoots markedly decreased the formation of new shoots. In our study, the shoots were propagated for three years and an efficient bulblet formation (Fig. 4d) was obtained (Podwyszyńska and Ross 2003). The bulblets were planted in soil and created new bulbs (data not presented). Thus, the potential for usability of TDZ in micropropagation of tulip was shown. However, the further observations of the flowering plants derived from such propagation system need further verification whether TDZ does not cause a somaclonal variation over the level countered in traditional tulip propagation. The flowering-size bulbs derived from the in vitro propagation under the influence of TDZ are expected next year.

\section{LITERATURE CITED}

ALDERSON P.G., TAEB A.G. 1990. Effect of bulb storage on shoot regeneration from floral stems of tulip in vitro. J. Hort. Sci. 65: 71-74.

BAKER C.M., WILKINS H.F., ASCHER P.D. 1990. Comparisons of precultural treatments and cultural conditions on in vitro response of tulip. Acta Hort. 266: 83-90.

CUSTERS J.B.M., EIKELBOOM W., BERGERVOET J.H.W., VAN EIJK J.P. 1992. In ovulo embryo culture of tulip (Tulipa L.); effects of culture conditions on seedling and bulblet formation. Sci. Hort. 51: 111-122.

CUSTERS J.B.M., EIKELBOOM W., BERGERVOET J.H.W., VAN EIJK J.P. 1995. Embryo-rescue in the genus Tulipa L.; successful direct transfer of $T$. kaufmanniana Regel germplasm into T. gesneriana L. Euphytica 82: 253-261.

GRAY D.J., BENTON C.M. 1991. In vitro micropropagation and plant establishment of muscadine grape cultivars (Vitis rotundifolia). Plant Cell Tiss. Org. Cult. 27: 7-14.

HUETTEMAN C.A., PREECE J.E. 1993. Thidiazuron: a potent cytokinin for woody plant tissue culture. Plant Cell Tiss. Org. Cult. 33: 105-119.

HUTCHINSON M.J., SAXENA.K. 1996. Role of purine metabolism in thidiazuron-induced somatic embryogenesis of geranium (Pelargonium $x$ hortorum Bailey) hypocotyl cultures. Physiol. Plant. 98: 517-522.

HULSCHER M., KRIJKSHELD H.T., VAN DER LINDE P.C.G. 1992. Propagation of shoots and bulb growth of tulip in vitro. Acta Hort. 325: 441-446.

KUIJPERS A.M., LANGENS-GERRITS M. 1997. Propagation of tulip in vitro. Acta Hort. 430: 321-324.

LENARD M., DUCOMMUN C., WEBER G., DORION N., BIGOT C. 1987. Observations sur la multiplication in vitro de la tulipe (Tulipa gesneriana L.) á partir de la hampes florales prélevées chez des bulbes en cours de conservation, Agronomie 7: 321-329.

MURASHIGE T., SKOOG F. 1962. A revised medium for rapid growth and bioassays, with tobacco tissue cultures. Physiol. Plant.: 15, 475-497.

NIIMI Y. 1978. Influence of low and high temperatures on the initiation and the development of a bulb primordium in isolated tulip embryos. Sci. Hort. 9: 61-69.

NIIMI Y. 1980. Histological observations on the initiation of the vegetative apex in tulip seeds cultured under low temperatures. Sci. Hort. 13: 161-171.

NISHIUCHI Y. 1979. Studies on vegetative propagation of tulip. 2. Formation and development of adventitious buds in the excised bulb scale cultivated in vitro. J. Japan. Soc. Hort. Sci. 48: 99-105. 
NISHIUCHI Y. 1980. Studies on vegetative propagation of tulip. 4. Regeneration of bulblets in bulb scale segments cultured in vitro. J. Japan. Soc. Hort. Sci. 49: 235-240.

PODWYSZYŃSKA M. 2001. Effect of carbohydrates on shoot multiplication and bulb formation of tulip in vitro. Roczniki Akademii Rolniczej w Poznaniu. Ogrodnictwo 33: 119-126.

PODWYSZYŃSKA M., GABRYSZEWSKA E., PRZYBYŁA A. 1998. Effect of growth retardants, cytokinin and auxins on the multiplication and rooting in vitro of Alstroemeria $x$ hybrida 'Juanita'. Acta Agrobotanica 51: 23-31

PODWYSZYŃSKA M., ROJEK A. 2000. Effect of light quality and darkness on tulip (Tulipa gesneriana L.) in vitro regeneration. Zeszyty Naukowe Instytutu Sadownictwa i Kwiaciarstwa w Skierniewicach 7: 130-137.

PODWYSZYŃSKA M., ROSS H. 2003. Formation of tulip bulbs in vitro. Acta Hort., in press.

PODWYSZYŃSKA M., SKRZYPCZAK C., FATEL K., GABRYSZEWSKA E., MARASEK A. 1997. Wpływ cytokinin i retardantów wzrostu na regenerację in vitro pędów przybyszowych na fragmentach pędu kwiatowego tulipana. In: Zastosowanie kultur in vitro w fizjologii roślin. Dubert F. and Skoczowski A. (eds.). ZFR PAN, Kraków, pp. 181-186.

PODWYSZYŃSKA M., SKRZYPCZAK C., FATEL K., MICHALCZUK L. 2001. Study on usability of Fusarium oxysporum Schlecht. f. sp. tulipae APT. metabolites for screening for basal rot resistance in tulip. Acta Arobotanica 54: 71-82.

PREECE J.E., IMEL M.R., 1991. Plant regeneration from leaf explants of Rhododendron 'P.J.M. Hybrids'. Scientia Hort. 48: 159-170.

RADEMACHER W. 1991. Inhibitor of gibberellin biosynthesis: applications in agriculture and horticulture. In: Gibberellins. Tanakahashi N., Phinney B.O., MacMillan J. (eds). Springer Verlag, Berlin, Germany, pp. 296-310.
RADEMACHER W. 2000. Growth retardants: Effects on gibberellin biosynthesis and other metabolic pathways. Annu. Rev. Plant Physiol. Plant Mol. Biol. 51: 501-531.

RICE R.D., ALDERSON P.G., WRIGHT N.A. 1983. Induction of bulbing of tulip shoots in vitro. Sci. Hort. 20: 377-390.

RIVIÈRE S., MULLER J.F. 1976. La multiplication végétative de la Tulipa gesneriana L. cultivar 'Paul Richter', par la culture in vitro des bourgeons axillaires des écailles. CR Séances Acad. Sci. Paris 282 (Série D): 533-536.

RIVIERE S., MULLER J.F. 1979. Ètude du bourgeonnement in vitro de l'écaille du bulbe de tulipe. Can. J. Bot. 57: 19861993.

TAEB A.G., ALDERSON P.G. 1990. Effect of photoperiod and quality of light on bulbing of tulip shoots regenerated in vitro. J. Hort. Sci. 65: 71-74.

THOMAS J.C., KATTERMAN F.R. 1986. Cytokinin activity induced by thidiazuron. Plant. Physiol. 81: 681-683.

WERBROUCK S.P.O., DEBERGH P.C. 1997. Possible role of gibberellins in the interactions between cytokinins and pesticides. Acta Hort. 447: 59-62.

VAN ROSSUM M.W.P.C., ALBERDA M., VAN DER PLAS L.H.W. 1997. Role of oxidative damage in tulip bulb scale micropropagation. Plant Science 130: 207-216.

VAN ROSSUM M.W.P.C., ALBERDA M., VAN DER PLAS L.H.W. 1998a. Tulipaline and tuliposide in cultured explants of tulip bulb scales. Phytochemistry 49: 723-729.

VAN ROSSUM M.W.P.C., DE KLERK G.J.M., VAN DER PLAS L.H.W. 1998b. Adventitious regeneration from tulip, lily and apple explants at different oxygen levels. J. Plant Physiol. 153: 141-145.

ZIV. M. 1990. The effect of growth retardant on shoot proliferation and morphogenesis in liquid cultured gladiolus plants. Acta Hort. 280: 207-214.

\title{
WPEYW TIDIAZURONU I PAKLOBUTRAZOLU NA ZDOLNOŚCI REGENERACYJNE EKSPLANTATÓW INICJALNYCH Z PĘDU KWIATOWEGO TULIPANA ORAZ NASTĘPCZO NA NAMNAŻANIE PĘDÓW
}

\author{
STRESZCZENIE
}

Badano wpływ tidiazuronu (TDZ) i paklobutrazolu na regenerację struktur podobnych do liści na fragmentach pędu kwiatowego 6 odmian tulipana oraz następczo na namnażanie pędów. Eksplantaty pobierano z cebul chłodzonych a następnie pędzonych. Eksplantaty inkubowano przez dwa miesiące w ciemności na zmodyfikowanej pożywce MS, uzupełnionej NAA i cytokininami - 2iP i BAP (w kontroli) lub zastępczo TDZ (0,5-4 mg l-1) i paklobutrazolem $\left(0,05-0,4 \mathrm{mg} \mathrm{l}^{-1}\right)$. Następnie regenerujące eksplantaty przeniesiono na pożywki zawierające TDZ i NAA w niskich stężeniach. Stwierdzono różnice w zdolnościach regeneracyjnych w zależności od odmiany i użytych regulatorów wzrostu. Procent eksplantatów regenerujących struktury podobne do liści w kombinacji kontrolnej wahał się od 80\% u odm. Blue Parrot i Prominence do poniżej 30\% u odm. Apeldoorn i Mirjoran. TDZ zastosowany w stężeniu optymalnym dla danej odmiany zwiększał procent regenerujących eksplantatów do 70\%$-100 \%$. Paklobutrazol wzmacniał reakcje eksplantatów, czego wynikiem była wysoka liczba tworzących się struktur podobnych do liści - w zależności od odmiany od 10 do 23 średnio na jednym eksplantacie. Regenerujące struktury, podobne do liści, rozwijały się stopniowo w charakterystyczne formy: rosnący do góry liść zarodkowy; u jego podstawy rozwijający się prawdopodobny zawiązek korzenia, skierowany przeciwnie do środka eksplantatu inicjalnego; następnie na przeciwnym biegunie liścienia, w dół do pożywki rozwijał się skrócony lub dłuższy stolon, na którego wierzchołku formował się merystem wierzchołkowy pędu. Przypuszcza się, że regeneracja bezpośrednia tych charakterystycznych struktur ma charakter embriogenezy somatycznej. Rozwijające się dalej pędy przybyszowe tworzyły kępy, które cyklicznie (co dwa miesiące) dzielono na 2-3 mniejsze. Regulatory wzrostu stosowane podczas stadium inicjalnego silnie wpływały na dalsze namnażanie pędów. Najbardziej intensywne tworzenie się pędów notowano, gdy zastosowano TDZ $\left(0,5-2 \mathrm{mg} \mathrm{l}^{-1}\right)$ i paklobutrazol $\left(0,05-0,1 \mathrm{mg} \mathrm{l}^{-1}\right)$.

SŁOWA KLUCZOWE: tulipan, regeneracja in vitro, mikrorozmnażanie, tidiazuron, paklobutrazol, somatyczna embriogeneza. 